found the first land mollusca on the Tchuktch Peninsula. Nordenskjöld considers it probable that on the southern part of this peninsula there was in former times a little inland ice. On July 3I the Vega was anchored at St. Lawrence Island. Drift ice was seen for the last time. The quantity of ice carried by the Polar current through Behring's Straits is very inconsiderable, and it has evidently been for the most part formed along the coast. Not a single iceberg was visible, the whole of the ice seen being level and rotten "year's ice." St. Lawrence Island is inhabited by Eskimo, who having frequent intercourse with the Tchuktches, have adopted some of their words. The prevailing rock is granite, weathering readily, and thus giving origin to a very fruitful soil. Vegetation was exceedingly luxuriant, and rich collections of land and marine animals, lichens, and algæ were made.

The Vega next anchored off Behring Island on August 14. This island belongs to Russia, but the American Alaska Company has acquired the right of hunting, and maintains a station where skins, principally those of the Otaria ursina, are purchased. Between 50,000 and I00,000 of these animals are killed yearly on this and the neighbouring Copper Island. They yield the brown "sealskin" so much in fashion in recent years. Behring's Island is supposed' to have been visited first by Behring, who, after being shipwrecked, died there in $174 \mathrm{I}$, survived, however, by many of his companions, among others, by the talented naturalist Steller, who described the natural history of the island in a misterpiece that has seldom been surpassed. Since Steller's time great changes have taken place. The Canis lagopus then occurred in incredible numbers. Now they are so uncommon that not one was seen, and those that remain are not dark blue, but white, the skins being of little value. On the neighbouring Copper Island dark blue foxes are still found in considerable abundance. In $174 \mathrm{I}-42$ Stellar and his companions killed here about 700 sea-otters. This animal, famous for its precious fur, is now quite extinct on Behring's Island. Of the sea-lion (Otaria stelleri), formerly abundant, only single specimens are to be found along with the sea-bear (Otaria ursina) on the rocky shores of the island, and the great sea-cow, the most remarkable of all the mammals formerly belonging to Behring's Island, is now completely extinct. Steller's sea-cow (Rhytina stelleri) was of a brownish colour, covered with hair which grew on a hide resembling the bark on an old oak. Its length, according to Steller, was sometimes as much as thirty-five feet and its weight nearly $50,000 \mathrm{lb}$. The female yielded abundance of milk, which, along with the flesh, resembled, and were even, according to Stellar, superior to those of the cow. The sea-cow fed on the abundant algæ along the coast in great herds. According to Midden lorf, the last sea-cow was killed in 1768. Nordenskjöld, however, found a "creole" of mixed Russian and Aleutian blood, whose father had come to the island in I777, and remembered the killing of sea-cows while they fed on seaweed at low water for the first two or three years (1779 or 1780 ) after his arrival. Nordenskjöld also found two men who had seen, about twenty-fire years ago, a large animal corresponding to Steller's seacow. He also obtained two complete skulls of the animal and a quantity of bones sufficient to fill twenty-one large boxes and barrells. The sea-bear (Otaria ursina) is the only large animal that exists on the island in about as large numbers as in Steller's time. It is "preserved" by the Alaska Company, only a limited number being killed yearly.

The vegetation on Behring's Island was found to be exceedingly luxuriant, and the sea in its neighbourhood one of the richest in algæ in the world. Forests of algæ, sixty to a hundred feet high, grew in favourable situations, rendering dredging exceedingly difficult. Some of the algæ are used by the natives as food.

The small streams swarmed with a number of different kinds of fish, among them a species of Coregonus, a little Salmo fario, a middle-sized salmon with nearly white flesh and a purple skin, and another of the same length, but very thick, and with a hump on its back. Other species of salmon with deep red flesh are found in the larger rivers. Leaving Behring's Island on August i9, the $V$ ega reached Yokohama on September 2 in good order and with every man on board in excellent health. There had not been a trace of scurvy during the whole voyage.

\section{GALILEO AND THE APPLICATION OF MATHEMATICS TO PHYSICS ${ }^{\mathrm{x}}$}

\section{II.}

I $N$ dealing with the falling body $I$ had to ask you to think what is the speed at any moment of a body which is changing its speed every moment, every half mornent, every hundredth part of a moment or what we call continuously. It is easy to see that it has some speed at every point, and that the speed at every point is quite definite. I indicated a way in which we could fix this approximately, by taking the average speed over short intervals. A similar question is raised in considering the path of the projectile. Its direction changes from point to point. The bullet is shot towards the east, and, for the sake of picturing its path, I imagine the lines vertically upward to be called northwards, as on a vertical map. At first the particle starts off, let me say, in a direction N.N.E. When it has reached the top of its path it is going horizontally-due east-when it has got back to the level the Northing has been turned into Southing, and it is going S.S.E. In its upward motion it changes continuously from N.N.E. to E. At a certain position it is half a point more to the east and less to the north; further on, a point more; further on again, the Northing has disappeared. The path has curved away; it is curving away at every point of it. A particle moving at a uniform rate in a circle changes its direction; but at every point the amount of curvature or immediate bending away from the direction in which the particle moves at any moment is the same. In a small circle the curve bends away faster than in a larger one from the line which represents the direction of motion at any point, but in each separate circle the measure of bending must at every point be the same. How will it be in a different kind of curve, such as an ellipse, or the path of a projectile, a parabola? As the speed of falling changes from moment to moment continuously, the curvature changes from moment to moment.

In solving the problems of falling bodies and of projectiles, Galileo was essentially applying the principles of the Differential or Fluxional or Indivisible Calculus. If pure mathematics had attracted him as strongly as its application to physics, he wou'd have thought these problems out, and would have founded the Fluxional Calculus, which is the glory of Newton and of Leibnitz. No doubt the world saw more in his great astronomical discoveries; in the telescope, which brought the moon thirty times nearer, and showed its mountains and the jagged edges of its gibbous side; in the discovery that Venus waxes and wanes with phases like the moon; in the four satellites of Jupiter, the famous Medicean stars, which showed the most restless activity of revolution round their central orb-an activity unprecedented in celestial bodies and discomposing to the Peripatetics, whose stately order of the heavens could not tolerate stars which behaved like sky rockets-of the curious double satellite of Saturn, which sometimes was even more bewildering, and went out altogether. It was the Ring, and Galileo gave what we now recognize as a very fail picture of it. No wonder that the man who first made the I An Introductory Lecture, by William Jack, M.A., L.L.D., F.R.S.E. St. Peter's Cillege, Cambridge. Continued from p. 43 
telescope a practical instrument could not lay it aside till he had exhausted what it had to tell him, or that his whole thoughts were turned from the mathematical and apparently abstract entities which we have been describing to discuss the system of the universe in the new light he had brought to bear on it. Yet the choice he made has proved to be wrong. It was through the door of mathematics-not through the tube of the telescope-that the discoveries of the true system of the universe were destined to pass. Galileo's facts made it practically certain that the Copernican theory was right, and that the sun was the centre of the orbit of each of the planets. Kepler enlarged these statements, establishing, by a patient industry that was never surpassed, that the orbits are ellipses nearly circles, with the sun in one focus-that the line drawn from sun to planet sweeps over equal areas in equal times-that the square of the time taken to describe a planet's orbit, divided by the cube of its mean distance from the sun, is a fraction which is the same for every planet of the system. Till Newton appeared to interpret them, these results were only statistical facts ; and Newton himself could throw no light on them till he had invented the Fluxional Calculus and discovered the properties of an abstract fluent quantity, such as a speed or a curvature, which is continuously changing.

And yet how near Galileo came to the secret! We have seen that he was in fact compelled to deal with the fundamental problems of the Fluxional Calculus in discussing falling bodies and projectiles. It was his famous scholar Cavalleri whose Calculus of Indivisibles foreshadowed the Fluxional Calculus of Newton. It is difficult to say how much of Cavalleri's views were developed out of the note-books of his master's lectures and out of his own consideration of the problems that master had triumphantly solved. Like many of Galileo's pupils, he had published works of his own, in which it was doubtless difficult to separate what was original from what was borrowed. From about 1592 till about 1638-forty-six years-Galileo had published scarcely anything except on the planetary system. The inclined planes, the falling bodies, the pendulums, the cycloids, were so many problems worked out in his youth-during the early years of his professoriates at Pisa and Padua-scattered in students' note-books, and germinating in students' minds throughout the world. It was so with his theory of projectiles; and Cavalleri, who was one of his old students and his successor at the University of Padua, published the theory of projectiles without referring it to its real author. Challenged by Galileo, he allowed his obligations frankly, and their frienclship was not interrupted. Cavalleri published his theory of indivisibles in Galileo's old age (1635), calling it "Geometria indivisibilibus continuorum nova quadam ratione promota," after he had apologised for his former awkward error. The shape of the new theory was Cavalleri's own-the impulse came almost certainly from the discoverer of the true theory of falling bodies and of projectiles.

We owe the theory of indivisibles to Cavalleri, and not to Galileo, partly, no doubt, because for the greater portion of his manhood his astronomical discoveries, and the discussions they brought with them, filled Galileo's mind almost exclusively; partly because for the last five-andtwenty years of his life most of his thought had to be spent on his relations with the Church, to which he was sincerely attached. In 1616 he was warned that the Copernican hypothesis was to be considered as false. Religious persecutions were not then unknown in Protestant countries, and people were tortured for witchcraft as well as heresy. But it was reserved to the Catholic Church in Italy to erect the Aristotelian doctrines and the Ptolemaic system into an article of faith. A century after Luther shook the world at Wittenberg, had brought dreadful days for mathematicians, physicists, and reformers, in Italy. When Galileo was a youth of twenty- three, two years before he was called to be professor at Pisa, Barozzi, who had occupied himself at Venice with the discussion of the asymptotes of curves, was believed to be guilty of dealing in sorcery and witchcraft, of casting lots, and of causing the drought which reigned in the Island of Cyprus. He was condemned by the Inquisition in 1587, partly because he had a great number of curious books and a wonderful collection of astronomical and mathematical instruments. Porta, the famous author of the "Magia Naturalis"-the reputed discoverer of the camera obscura, - was summoned to Rome to give an account of his opinions. Giordano Bruno was burned at Venice in 1600, hardly less for his daring speculations in religion than because he had attacked Aristotle and adopted the system of Copernicus. The aged Archbishop of Spalatro, de Dominis, to whom Newton attributes the successful explanation of the colours of the rainbow, died in 1624 in the prisons of the Inquisition, and all that death had left to the mercies of his persecutors was publicly committed to the flames. The skies of Italy were black with the smoke of these burnings, the air was heavy with suspicion and terror. The Inquisition tried men for heresies which had been denounced by unknown enemies, and the processes of moral and intellectual torture to which it subjected those who were brought before its tribunals were only more oppressive because the secret of their details was closely kept. Galileo wrote a letter to his friend and pupil the Jesuit Castelli, in 1614, copies of which were privately circulated, but which was not printed till twenty years later. In that noble writing he lays down with equal firmness and clearness the broad lines with separate scientific and religious thought, and shows himself deeply penetrated with religious as with scientific faith. A Jesuit father denounced it, another preached against him as a witness for the Copernican system. Though the great works he had hitherto published, that on the Solar Spots and the "Nuncius Sidereus" had neither of them committed their author to the Copernican theory of the universe, the Church resolved to anticipate and to forbid the support by the most illustrious of living astronomers of doctrines, which, whatever else might be said of them, were clearly fatal to the authority of the Peripatetics.

Galileo went to Rome (in 1616) to struggle for as much liberty as could be saved, but he was deeply disappointed with the result. He retracted nothing, because he had neither been tried nor convicted, but the officers of the Inquisition waited on him, and left him an official warning that it was not permitted to teach that the sun was the fixed centre of our system, and that the earth revolved around it. Silence was imposed on him; and it was only after the new Pope was appointed, who, as a Cardinal, had opposed the promulgation of this warning, that he ventured again to think of publishing his views. The book in which they appeared in 1632 was a three-cornered dialogue between a Ptolemaist and a Copernican, with a third person acting as a kind of half intelligent chorus. The arguments of the Ptolemaist were, of course, the weaker, as in Galileo's hands it was impossible that it should be otherwise. To secure the imprimatur of the censorship, he prefixed this statement to the book-"Within the last few years a salutary edict was promulgated at Rome, in which, in view of dangerous scandals, silence was enjoined on the supporters of the Pythagorean doctrine of the movement of the earth. Some have been rash enough to say that this dogma was not arrived at after a judicious examination, but was promulgated in passion and in ignorance, and it has been asserted that people utterly without practice in astronomical observations ought not to attempt, by a premature prohibition, to clip the wings of speculation. Hearing these complaints my heart burned within me, and I could not keep silence. Having been fully informed of this wise decision, I resolved to 
appear publicly before all the world, and to testify to the truth. I was at Pome at the time. I was listened to and praised by the most eminent prelates, and was at once acquainted with this decree. My purpose in this book is to show foreign nations that in Italy, and especially in Rome, as much is really known about these matters as anywhere else. I have gathered together my speculations on the Copernican system to show that all these things were known before the condemnation, and that we owe to Italy not merely doctrines for the salvation of their souls, but ingenious discoveries to delight the minds of men." The elaborate and somewhat overstrained courtesy of this preface availed as little to save its author from the terrors of the Inquisition as the imprimatur of the Papal censorship which he had procured beforehand. The Pope looked on the soi-disante hypothetical presentation of Copernicanism as a mere pretence. I need not repeat the well-known story of the great man's sufferings. After long months of mental torture, he was dragged before the sacred tribunal, and compelled to confess that he had been criminally negligent in stating too cogently the arguments for the Copernican system in the eagerness of intellectual debate, and in not sufficiently guarding the hasty reader against the force of arguments for what the Church had pronounced to be dangerous heresy. At the age of seventy the greatest discoverer - the most distinguished man in Europe-was threatened with torture to extract from him, if possible, the confession that he had had a malicious intention of unsettling men's faith in divine truth. It had been privately decided by the Pope that if the threat of torture failed, the Inquisition was not to proceed to the last extremity. Galileo knew nothing of this, but the threat did fail. For his rashness he was sent to the prisons of the Inquisition. $\mathrm{He}$ was released in a few days, but he was ordered to confine himself within four walls and his successive places of seclusion were marked out for him. His visitors were noted, and he was warned that an imprudent word might bring him back to the dungeons from which he was only respited on his good behaviour. Private orders were given to the censorship throughout Italy that he was not to be permitted to publish anything, not even to re-issue the treatises which first made him illustrious. It was a living death to which his judges had consigned him, and he was reduced to permit his friends to publish surreptitiously across the Alps the book which summed up the long work of his life in Mathematics, in Mechanics, in Hydrostatics, in Physics, so far as Physics were then possible. His greatest work, the "Discorsi e Dimostrazioni Matematiche," "on two new sciences," appeared in France, and, to save him from the risk of torture, the miserable pretence had to be put forward even there, that the manuscript had been taken away by one of his friends. In 1637 , in his seventy-third year, he lost his eyesight ; in $164 \mathrm{I}$ he died.

The eight years during which the broken-hearted old man, from whose outward eyes the light of that universe, which he had done more than all his predecessors to reveal to men, was fast fading, were the most memorable in the history of modern science. Much of the work he published in them had previously been scattered over Europe by his pupils, but none of them all had his migh 'y sweep of thought, his noble style, his all-illuminating insight. Had his enemies succeeded in silencing him, had he been handed over to the rack at seventy, or prevented, as they meant he should be, from speaking once more urbi et orbi, for fear his words might shatter the system of Ptolemy or put an end to that worship of a traditional philosophy which he had conquered, and which was struggling to strangle him in its death throes, the world might have waited a century longer for Torricelli and Pascal, for Newton and Laplace. In these last years he is greater and maturer than ever. Banished from the skies by the jealousy of philosophers and priests, he comes back to earth and lays deep and sure those foundations of mechanics without which it was impossible to carry further the science of the heavens. His watchword was that phenomena must first be measured before the attempt to explain or to co-ordinate them. Physics and Astronomy can rest only on mathematics, and the secrets of that hand which laid the foundations of the world in measure are only to be learned by patient and exhaustive observation, and by thought built upon and not preceding it.

Let me give you one last illustration of his method in his invention of a heat measurer. Every one seems to know what is heat and what is cold. They are among the most familiar of our sensations. But my sensations may differ from yours. I may pronounce a body hot which you may call cold; and before Galileo's time there was no apparent way of settling the dispute except by declaring it a matter of taste, and agreeing to differ. He invented a measuring instrument-the progenitor of our thermometers. Imagine a flask with a bulb blown out at the end of it, and a long tube of uniform bore for a neck, such as we see in a thermometer. Let the bulb be partly filled with coloured water. Put the finger at the end to keep the water in; turn the tube upside down so that the bulb is at the top and the tube vertical. Plunge the end of the tube in a vessel of water, and then remove the finger. All the coloured water will not flow down into the vessel. If the bulb is surrounded by something warmer than itself, the level will fall till it nearly reaches the water in the basin; if it is surrounded by something colder, the level will rise. Galileo had found a phenomenon accompanying an increase or diminution of heat as unvaryingly as a shadow follows its substance. Like the shadow, this new phenomenon is measureable, and though it was too soon to say that the rise or fall in the tube was in any exact proportion to the diminution or increase of the surrounding heat, it was easy to establish the fact that a rise always meant a diminution and a fall an increase. It was not given to Galileo to discover those properties of air and gases which turn the thermoscope into the air thermometer, the most sensitive and accurate of heat measurers. Had he known them, he was far enough in the way which his pupil Torricelli followed to have discovered the barometer also, and to have measured the weight of a column of that great atmospheric ocean at the bottom of which man lives as the Bathybius is supposed to live at the bottom of the watery deeps. Even there his sagacity had divined the necessity of applying measurement to that horror of a vacuum which before his time had only been a philosopher's name for our ignorance of a cause.

I have certainly failed in my object to-day if I have not conveyed to you two truths which lie at the basis of modern science. It is the first, perhaps, with which I have most to do as a teacher, and you as students of pure mathematics. The sciences of measurement, the methods of measurement-sciences and methods which are abstract in form, but which are constantly applied to concrete things, - are the true keys to the sciences of experiment. It was in the apparently intricate abstractions of continuous change of velocity and of curvature, in the apparently curious considerations of the science of indivisibles, the beginnings of which we owe to Galileo, that Newton found that secret of the universe which transformed the life-long labours of Kepler, the great statist of astronomy, into the law of gravitation. The fascinations of astronomy, and the fatal chains which hung about his later life, like those which Samson had to bear when he made mirth for the Philistines, combined to deprive Galileo of the honours which awaited Newton. But that lesson need not be lost to us. My second lesson is that measurement-measurement even in its simplest form, mathematics, or, if you choose, arithmetic, - lies at the root of all our knowledge of nature.

If I have one word more to say about the great Florentine to my students, it will not be of the pity of it all, of the terror and the tragedy in which his life closed; 
it will be to ask them to remember that he proved, what the gieatest men have always proved, that it is possible to conciliate the most magnificent knowledge of mathematics or of any abstract science with all the culture of the time. Galileo was an admirable writer; he was a great musician; he studied Ariosto and Dante with intense love; he amused himself with comedy; he distinguished himself in painting. It is the commonplace of the history of great men-a commonplace better illustrated perhaps by the great names of Italy than by those of any other country-that greatness is scarcely compatible with a narrow concentration of intellect, even to one great family of subjects. Many of her great mathematicians were sculptors, painters, poets, masters of expression. But if the story of Galileo's life should guard you from falling into the Scylla of the eager student who thinks that he must dwarf his nature if he hopes to attain to eminence in a special subject-an error to which the pressure of our times renders him more and more liable - it is equally certain to save him from the Charybdis of the dilettante who forgets to choose that one of the objects attainable within the little compass of a man's life which is most suited to his faculties, and in attaining which he is most likely to succeed, Galileo repressed none of his great powers, and denied himself none of the intellectual delights which few men of his day were so able to enjoy. But the obstinacy with which he followed after mathematical and physical truth, from the day when he first listened, as a truant medical student, at the key-hole of a lecture-room to the professor of mathematics teaching the Grand Duke's pages, to that, nearly sixty years after, when the worn-out shell which had suffered so much was laid in that last darkness of the grave, warns us that greatness is never, and, I may add, success is seldom, won without an unfaltering perseverance in the pursuit of the main object of life. The last wish of the venerable old man, whose heart suffered as much from the cruelty which had cut him off, in a sense, from the outward communion of the faithful, as his intellect did when he was compelled, on his knees, to deny what he had proved to be the true system of the universe, was refused him. The Church below refused him burial in the Santa Croce at Florence, but it could not prevent the eyes that old age and suffering had blinded to the delights of his Italian earth from opening on the splendours of an immortality which no man has better earned.

\section{WHO WAS PRINCE ALUMAYÛ?}

$\mathrm{SOME}$ of our contemporaries, referring to the recent death of King Theodore's son, Prince Alumayû, speak of him as if he were an African of the ordinary Negro type. This is perhaps on the whole a fair gauge of the popular ideas still prevalent regarding the natives of the Dark Continent. Yet, though the standard is not of a high order, it must be confessed that in the present case some little confusion might well be pardoned, considering the many difficulties attaching to the subject of Abyssinian ethnology. Indeed it would be no easy matter even for a sound ethnologist to answer the question off-hand, who was Prince Alumayû ? To do so accurately implies a clear knowledge of a very complicated problem, to the elucidation of which a few lines may be welcomed by the readers of NATURE, in connection with an event of some political importance and presenting a very striking parallel in more than one respect to the death of the late Prince Louis Napoleon in Zululand.

It may at once be stated that, whatever else he may have been, the young "Ethiopian," as he has been called, was in no sense an African Negro, and that matters will be much simplified if the "Negro question" be dismissed altogether from the present discussion. There no doubt is some true Negro blood in the lowlands, especially towards the south-west frontier bordering on Senaar ; but in the Abyssinian highlands proper the Negro element seems never at any time to have been present, and at any rate King Theodore of Amhara was no more of Negro stock than are the Rajputs of Northern India. The types have nothing in common except the outward element of colour, though even here great differences prevail, and many of the Abyssinians, especially the women, are rery fair. In all other respects-physique, language, mental qualities - the divergence is fundamental.

This statement applies not only to the ruling peoples of Tigré, Amhara, and Shoa-the "Habesh" properwho are intruders, but also to the true aborigines whether settled or nomad, and who may, for convenience, be here collectively grouped as Agaui, the 'A $y a u$ of Cosmas (about 520 A.D.). The Habesh belong to the Himyaritic branch of the great Semitic family, and must have found their way into the country from the south-western parts of Arabia many hundred years before the Christian era. The Agaii are a section of the Hamitic family intermediate between the Gallas and Somâli of the south, and the Bisharas or Bejas and Egyptians further north. But Semite and Hamite, both originally no doubt one, are themselves mere varieties of the great "Caucasian" type, of which the Aryans are a collateral branch. It follows therefore that Abyssinia is peopled exclusively by races fundamentally distinct from the African Negro, and remotely allied to the fair European stock. Hence Prince Alumay û's affinities are, not with the black inhabitants of the Dark Continent, but with the light, swarthy, and dark peoples of Europe, South-Western Asia, and Northern India.

It will now be more easy to determine his position in the Abyssinian family itself. Although in this area the fundamental elements, as shown, are two only, Hamite and Semite, the intermingling of these elements, continued during a period of probably not less than four thousand years, and taking place under ever-varying conditions, has resulted in no little confusion, and the perplexity has in this case been further intensified by the elements of speech and religion. Thus, the Amharic people, for instance, are usually classed as "Habesh" proper, because of their language ; for Ambarna, notwithstanding many serious differences, is no doubt fundamentally related to the Tigrâi, the purest representative of the old Ghêz (Himyaritic), extinct since the fourteenth century. But it might not be difficult to show that the bulk of the Amharic ${ }^{1}$ nation are ethnically of Agai stock, though now speaking a modified Ghêz dialect imposed upon them by the conquering Semites from the north. At the same time the dominant race in Amhara is no doubt still more akin to the Semites than to the subject race. Hence the late Prince Alumayû, belonging to the royal blood of Amhara, must, on the whole, be regarded as of Habesh (Himyaritic) stock as well as speech.

Religion has been mentioned as a source of confusion, and an obvious case in point are the mysterious Falashas, who, because professing the Jewish faith, are popularly supposed to be of Hebrew nationality. Fortunately, Mr. Edward Hine has not yet got hold of them, and they have consequently not yet been identified with any of the lost tribes. Nevertheless, their position is sufficiently curious and interesting, though it may now be stated with some confidence that they are neither Jews, Israelites, nor Semites. In speech and physique they are a distinct branch of the Agaü (Hamitic) family, and can no more be converted into descendants of Abraham by the practice of maimed Abrahamitic rites than the adoption of Islám can transform the Chinese Panthays into Koreish Bedouins.

The subjoined scheme of the various races now in possession of the Habesh highlands may help to clear up

The very word Amhara has been identified with the Hamra, the chief Agaü nation in the Takazzé valley and province of Lasta, Tigré. 